\title{
INFLUENCE OF TREATED SEWAGE SLUDGE APPLICATIONS ON CORN AND SECOND CROP WHEAT YIELD AND SOME PROPERTIES OF SANDY CLAY SOIL
}

\author{
Sezai DELIBACAK*, Ali Riza ONGUN \\ Ege University, Faculty of Agriculture, Department of Soil Science and Plant Nutrition, Izmir, TURKEY \\ ${ }^{*}$ Corresponding author: sezai.delibacak@ege.edu.tr
}

Received: 16.09.2015

\begin{abstract}
The objective of this study is to determine influence of treated sewage sludge (TSS) rates on corn and second crop wheat yield and some properties of sandy clay soil. The field study was conducted in 20 plots in a randomized block design with four replications and five different applications including control, mineral fertilizer and TSS (12.5; 25.0; $37.5 \mathrm{Mg.ha}^{-1}$ as dry matter). Corn (Zea mays L. var. ZP 737) was the first crop, wheat (Triticum durum L. var. Ege 88) was the second crop. Soil samples were taken five times in two years. Increasing TSS applications resulted in significantly increased total biomass and grain yield of corn. However, grain yield of second crop wheat did not change significantly. Increasing TSS aplications were significiantly increased total $\mathrm{N}$, available $\mathrm{P}$ and $\mathrm{K}$, $\mathbf{p H}$, total salt and organic matter content of sandy clay soil. However, $\mathrm{CaCO}_{3}$ and cation exchange capacity values of soil did not change significantly. Due to decomposition of TSS in the soil, effect of TSS levels on soil properties decreased in the last sampling periods. Thus, it can be

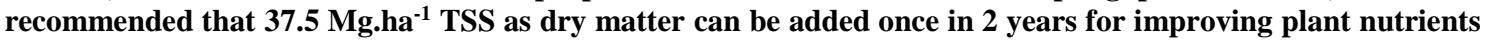
and soil properties of sandy clay soil.
\end{abstract}

Keywords: corn, sandy clay, sewage sludge, soil properties, wheat

\section{INTRODUCTION}

Wastes and by-products, which are organic residual from different processes, have beneficial properties when added to soil. When correctly applied, organic residues can restore soil quality, by balancing $\mathrm{pH}$, increasing soil organic matter $(\mathrm{OM})$, enlarging carbon reservoirs, increasing porosity, soil aggregation and water retention capacity, improving fertility and stimulating microbial communities. Thus, amelioration of soil conditions enables vegetation development, increasing productivity. Treated sewage sludge (TSS) is an ultimate product of municipal wastewater treatment plant and highly enriched in OM. Sewage sludge gives us the opportunity of beneficial use by closing the cycle of nutrients (Sequi et al., 2000). At present the major ways of disposing of sewage sludges are deposition, landfill and incineration, only part of the sludges are used in agriculture. Where sludge is to be used on land, it is usually stabilised by mesophilic anaerobic digestion, or aerobic digestion and then treated with polymers and mechanically dewatered using filter presses, vacuum filters or centrifuges. Other treatment processes for sludge going to land include long-term storage, conditioning with lime, thermal drying and composting. As municipalities upgrade waste water treatment systems and public opinion and legislation discourages disposal of organic materials in landfills, biosolids are projected to become increasingly available for agricultural use. Organic materials can differ considerably in terms of the extent to which they increase soil organic matter contents and alter soil physical and chemical properties (Barker et al., 2000). Sewage sludge may contain significant amounts of N, P and trace elements. The use of sewage sludge has been recommended to improve the chemical and physical properties of soil (Wong and Su 1997; Debosz et al., 2002). The beneficial effects of using sludge on agricultural soils have been proven by numerous researchers (Wong and $\mathrm{Su}$ 1997; Aggelides and Londra 2000; Benitez et al. 2001; Selivanovskaya et al. 2001; Debosz et al. 2002). The use of biosolids as agricultural soil amendments and fertiliser replacements is also relatively well researched (Cogger et al. 2004; Corre^a 2004; Tarraso'n et al. 2008; Delibacak et al. 2009a), and fertiliser advice is available for these materials (Defra 2010). TSS contains macronutrients, trace elements and heavy metals. These attributes potentially make TSS an excellent fertilizer at very low cost for agricultural land in Turkey which is generally rich in lime, low in OM. However, special care should be taken with respect to micronutrients and heavy metals so as not to introduce excessive amounts of these elements, which could have an adverse effect on the environment, especially when soil is acidic (Delibacak et al. 2009a; Mercik et al. 2003, Pascual et al. 2004). The purpose of this work has 
been to evaluate the influence of municipal TSS doses on the corn and second crop wheat yield and some properties of sandy clay soil during five different periods in two years.

\section{MATERIALS AND METHODS}

\section{Experimental site}

The experiment was conducted at the research field of Aegean Agricultural Research Institute in Menemen plain, Izmir, Turkey $\quad\left(38^{\circ} 56^{\prime} 29.02^{\prime \prime}-38^{\circ} 56^{\prime} 37.59^{\prime \prime} \mathrm{N}\right.$; $\left.27^{\circ} 05^{\prime} 23.08^{\prime \prime}-27^{\circ} 05^{\prime} 30.74^{\prime \prime} \mathrm{E}\right)$. The experimental site is in the Western Anatolia region of Turkey (Figure 1), where the Mediterranean climate prevails with a long-term mean annual temperature of $16.8{ }^{\circ} \mathrm{C}$. Long-term mean annual precipitation is $542 \mathrm{~mm}$, representing about $75 \%$ of rainfalls during the winter and spring, and the mean relative humidity is $57 \%$. Long-term mean annual potential evapotranspiration is $1,570 \mathrm{~mm}$ (IARTC 2012). The investigated soil is characterized by sandy clay texture with slightly alkaline reaction and classified as a Typic Xerortent (Soil Survey Staff 2006). Some selected properties of experimental soil is given in Table 1 and some selected properties and total heavy metal concentrations in TSS used in the experiment is given in Table 2.

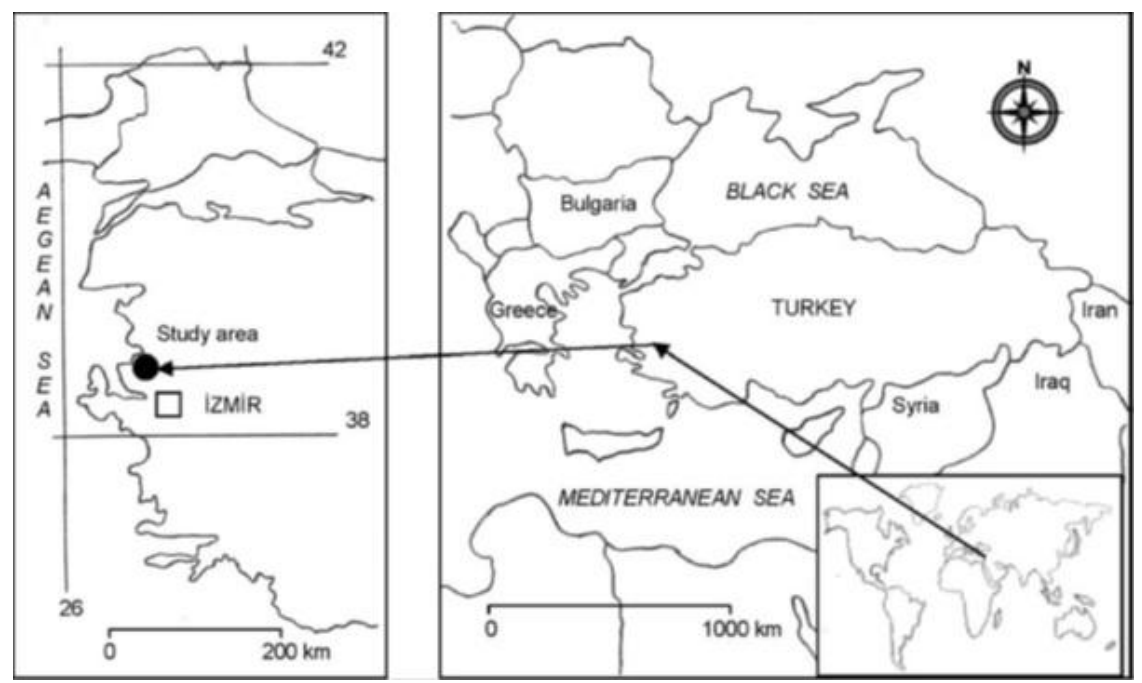

Figure 1. Location of study area

Table 1. Some selected properties of experimental soil

\begin{tabular}{lll|lll}
\hline Sand & $(\%)$ & 44.84 & $\mathbf{p H}$ & $($ Saturation paste) & 7.53 \\
Silt & $(\%)$ & 16.44 & Salt & $(\%)$ & 0.167 \\
Clay & $(\%)$ & 38.72 & CaCO3 & $(\%)$ & 0.51 \\
Texture & & Sandy clay & OM* & $(\%)$ & 0.94 \\
\hline
\end{tabular}

*OM:organic matter

Table 2. Some selected properties and total heavy metal concentrations of treated sewage sludge used in the experiment

\begin{tabular}{lll|lll}
\hline $\mathbf{E C}$ & $\mathrm{dS} / \mathrm{m}$ & 16,35 & $\mathbf{F e}$ & $\%$ & 1,14 \\
$\mathbf{C a C O} \mathbf{3}$ & $(\%)$ & 10,24 & $\mathbf{C u}$ & $\mathrm{mg} / \mathrm{kg}$ & 268,8 \\
Org. matter & $(\%)$ & 70,32 & $\mathbf{Z n}$ & $\mathrm{mg} / \mathrm{kg}$ & 1335 \\
Org. C & $(\%)$ & 40,79 & $\mathbf{M n}$ & $\mathrm{mg} / \mathrm{kg}$ & 298,6 \\
$\mathbf{N}^{1}$ & $(\%)$ & 5,33 & $\mathbf{B}$ & $\mathrm{mg} / \mathrm{kg}$ & 035,2 \\
$\mathbf{P}^{1}$ & $(\%)$ & 1,33 & $\mathbf{C o}$ & $\mathrm{mg} / \mathrm{kg}$ & 014,2 \\
$\mathbf{K}^{1}$ & $(\%)$ & 0,68 & $\mathbf{C d}$ & $\mathrm{mg} / \mathrm{kg}$ & 004,1 \\
$\mathbf{C a}^{1}$ & $(\%)$ & 3,74 & $\mathbf{C r}$ & $\mathrm{mg} / \mathrm{kg}$ & 250,6 \\
$\mathbf{M g}^{1}$ & $(\%)$ & 0,68 & $\mathbf{N i}$ & $\mathrm{mg} / \mathrm{kg}$ & 115,4 \\
$\mathbf{N a}^{1}$ & $(\%)$ & 0,59 & $\mathbf{P b}$ & $\mathrm{mg} / \mathrm{kg}$ & 199,4 \\
${ }^{1}$ Total & \multicolumn{7}{|r}{}
\end{tabular}

\section{Field experiment}

The field study was conducted in 20 plots in a randomized block design with four replications and five different applications including control, mineral fertilizer, treated sewage sludge 12.5 Mg.ha' ${ }^{-1}$ 25.0 Mg.ha ${ }^{-1}$; 37.5 ${\mathrm{Mg} . h a^{-1}}$ as dry matter during 2011-2012. The plot dimensions were $3 \mathrm{~m}$ width and $3 \mathrm{~m}$ length. The TSS used in the experiment was obtained from the wastewater treatment plant of Metropolitan Region, Izmir city. It may produce around $600 \mathrm{Mg}$ (moist basis) sewage sludge per day. Calcium oxide was added to raise the efficiency of the dewatering process of sewage sludge. In addition, the SS produced presented a $\mathrm{pH}$ varying between 10 and 13 , what increased the pathogen control and decreased the heavy metal availability by added calcium oxide. TSS was added

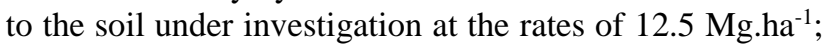
25.0 Mg. ha ${ }^{-1}$; $37.5 \mathrm{Mg}$. ha $^{-1}$ as dry matter on July 14, 2011. Also $150 \mathrm{~kg} \mathrm{~N}, 150 \mathrm{~kg} \mathrm{P}_{2} \mathrm{O}_{5}, 150 \mathrm{~kg} \mathrm{~K}_{2} \mathrm{O} \mathrm{ha}^{-1}\left(1000 \mathrm{~kg} \mathrm{ha}^{-}\right.$ 1 15.15.15. composed fertilizer) were applied to the only mineral fertilizer parcels at the same time and mixed with soil to $15 \mathrm{~cm}$ depth. Corn (Zea mays L. var. ZP 737) was sown with seeding machine on rows $18 \mathrm{~cm}$ and in rows 70 $\mathrm{cm}$ apart. Drop irrigation was provided when required. Harvest of corn was done by hands on November 17, 2011. Wheat (Triticum durum L. var. Ege 88) was sown with seeding machine on November 22, 2011 to $5 \mathrm{~cm}$ of soil depth as second crop. Also $80 \mathrm{~kg} \mathrm{~N}$ and $80 \mathrm{~kg} \mathrm{P}_{2} \mathrm{O}_{5} \mathrm{ha}^{-1}$ (400 $\mathrm{kg} \mathrm{ha}^{-1} 20.20 .0$. composed fertilizer) were applied to 
the only mineral fertilizer parcels at the same time and mixed with soil to $15 \mathrm{~cm}$ depth before wheat seeding. Wheat was harvested with machine on July 10, 2012. Second year, without applying any TSS (for determination of its second year effect), corn seeds were sown with seeding machine on July 18, 2012. Also $150 \mathrm{~kg} \mathrm{~N}, 150 \mathrm{~kg}$ $\mathrm{P}_{2} \mathrm{O}_{5}, 150 \mathrm{~kg} \mathrm{~K} \mathrm{O}_{2} \mathrm{ha}^{-1}$ were applied to the only mineral fertilizer parcels at the same time and mixed with soil to 15 $\mathrm{cm}$ depth before corn seeding. Harvest of second year's corn was done by hands on November 1, 2012.

\section{Soil sampling and analyses}

During the experiment, soil samples were taken from the center of each plot in five different periods (1st, August 11, 2011-3 weeks after sowing of corn; 2 nd, November 17 , 2011-after corn harvest; 3rd, July 11, 2012-after wheat harvest; 4th, August 7, 2012-3 weeks after sowing of second year corn; 5th, November 1, 2012- after corn harvest of second year). The samples were air-dried and sieved using 2-mm sieve. All analysis were done in these sieved soils. Particle size distribution of experimental soil was determined by the Bouyoucos hydrometer method (Bouyoucos 1962). Total salt, $\mathrm{OM}$ concentration, $\mathrm{CaCO}_{3}$, $\mathrm{pH}$, total $\mathrm{P}, \mathrm{K}, \mathrm{Ca}, \mathrm{Mg}, \mathrm{Na}, \mathrm{Fe}, \mathrm{Cu}, \mathrm{Mn}, \mathrm{Zn}, \mathrm{Cd}, \mathrm{Cr}, \mathrm{Co}, \mathrm{Ni}$, $\mathrm{Pb}$ and $\mathrm{B}$ concentrations of TSS were all determined according to Page et al. (1982). Some properties (total salt, $\mathrm{OM}$ concentration, $\left.\mathrm{CaCO}_{3}, \mathrm{pH}\right)$ of the soil were also determined according to Page et al. (1982). Cation exchange capacity (CEC) of experimental soil was determined according to Chapman (1965). Total N content of soil and TSS were determined using a modified Kjeldahl method (Bremner 1965). Available $\mathrm{P}$ in soil was determined by the Mo blue method in $\mathrm{NaHCO}_{3}$ extract (Olsen et al., 1954). Available K was analyzed with $1 \mathrm{~N}$ $\mathrm{NH}_{4} \mathrm{OAc}$ extract method (Kacar 1994).

\section{Statistical analysis}

Data were analyzed using the Statistical Package for the Social Sciences (SPSS) version 17 (SPSS 17.0 2008). Tukey test was used to find if differences in the treatments were significant at $\mathrm{P} \leq 0.01$ or $\mathrm{P} \leq 0.05$.

\section{RESULTS AND DISCUSSION}

\section{Influence of TSS applications on yield of corn and second} crop wheat grown in sandy clay soil

Influence of TSS applications on total biomass and grain yield of corn grown in sandy clay soil are given in Table 3 and Table 4, respectively. The increasing TSS rates significantly increased average of 1 st and 2 nd year total biomass and grain yield of corn in the experiment. Antolı'n et al. (2005) stated that the yield of barley increased in sludge and mineral amended plots in comparison to unamended plots. The higher yields in sludge-treated crops are usually attributed to an improvement in the soil conditions, by the supply of additional $\mathrm{C}$ from the sludge (Navas et al. 1998; Christie et al. 2001). Daur et al. (2015) showed that increasing levels of organic manure and humic acid enhance nutrient uptake and increase crop yield of organic berseem.

Table 3. Influence of treated sewage sludge (TSS) applications on total biomass yield of corn grown in sandy clay soil, Tukey: $\mathrm{P} \leq 0,01$

\begin{tabular}{|c|c|c|c|c|c|c|}
\hline Applications & $\begin{array}{c}\text { Average of 1st and } \\
\text { 2nd. year yield } \\
\left(\mathrm{Mg.ha}^{-1}\right) \\
\end{array}$ & $\begin{array}{c}\text { 1st year yield } \\
\left(\mathrm{Mg} \mathrm{ha}^{-1}\right)\end{array}$ & & $\begin{array}{c}\text { 2nd year } \\
\text { yield } \\
\left(\mathrm{Mg.ha}^{-1}\right)\end{array}$ & & \\
\hline Control & $33.51 \mathrm{~b}^{1}$ & $34.75 \mathrm{c}$ & $\mathrm{A}^{2}$ & $32.28 \mathrm{a}$ & $\mathrm{A}$ & \\
\hline Fertilizer & $37.55 \mathrm{ab}$ & $43.09 \mathrm{bc}$ & $\mathrm{A}$ & $32.02 \mathrm{a}$ & A & \\
\hline 12.5 Mg.ha-1 TSS & $40.06 \mathrm{ab}$ & $49.37 \mathrm{abc}$ & $\mathrm{A}$ & $30.75 \mathrm{a}$ & B & $* *$ \\
\hline 25.0 Mg.ha-1 TSS & $44.21 \mathrm{ab}$ & $52.67 \mathrm{ab}$ & A & $35.76 \mathrm{a}$ & B & $* *$ \\
\hline 37.5 Mg.ha-1 TSS & $47.62 \mathrm{a}$ & $59.78 \mathrm{a}$ & A & $35.47 \mathrm{a}$ & B & $* *$ \\
\hline
\end{tabular}

Significant differences between treatments at ** $\mathrm{P} \leq 0,01$ or $* \mathrm{P} \leq 0,05$ level indicated by different letters. ${ }^{1}$ Small letter in column for applications, ${ }^{2}$ capital letter in row for years.

Table 4. Influence of treated sewage sludge (TSS) applications on grain yield of corn grown in sandy clay soil Tukey: $\mathrm{P} \leq 0,01: \mathrm{P} \leq 0,05$

\begin{tabular}{|c|c|c|c|c|c|c|}
\hline Applications & $\begin{array}{c}\text { Average of 1st and } \\
\text { 2nd. year yield } \\
\left(\mathrm{Mg.ha}^{-1}\right)\end{array}$ & $\begin{array}{c}\text { 1st year yield } \\
\left(\mathrm{Mg.ha}^{-1}\right)\end{array}$ & & $\begin{array}{c}\text { 2nd year } \\
\text { yield } \\
\left(\text { Mg.ha }^{-1}\right) \\
\end{array}$ & & \\
\hline Control & $3.11 \mathrm{c}^{1}$ & $3.31 \mathrm{c}$ & $\mathrm{A}^{2}$ & $2.91 \mathrm{~b}$ & $\mathrm{~A}$ & \\
\hline Fertilizer & $4.81 \mathrm{bc}$ & $6.47 \mathrm{~b}$ & $\mathrm{~A}$ & $3.14 \mathrm{ab}$ & B & $* *$ \\
\hline 12.5 Mg.ha ${ }^{-1} \mathrm{TSS}$ & $5.19 \mathrm{bc}$ & $7.72 \mathrm{ab}$ & $\mathrm{A}$ & $2.66 \mathrm{~b}$ & B & $* *$ \\
\hline $25.0 \mathrm{Mg} \cdot \mathrm{ha}^{-1} \mathrm{TSS}$ & $6.16 \mathrm{ab}$ & $8.59 \mathrm{ab}$ & A & $3.73 \mathrm{ab}$ & $\mathrm{B}$ & $* *$ \\
\hline $37.5 \mathrm{Mg} \cdot \mathrm{ha}^{-1} \mathrm{TSS}$ & $7.69 \mathrm{a}$ & $10.19 \mathrm{a}$ & A & $5.20 \mathrm{a}$ & $\mathrm{B}$ & $* *$ \\
\hline
\end{tabular}

Significant differences between treatments at $* * \mathrm{P} \leq 0,01$ or $* \mathrm{P} \leq 0,05$ level indicated by different letters. ${ }^{1}$ Small letter in column for applications, ${ }^{2}$ capital letter in row for years. 
Influence of TSS applications on grain yield of second crop wheat grown in sandy clay soil are given in Table 5 .

The highest grain yield of wheat as second crop was found with the highest TSS application dose. Hernandez et al. (1991), Jamil et al. (2004), Jamil et al. (2006) and Tamrabet et al. (2009) reported that sewage sludge increased the grain yield and straw production of wheat. They mentioned that the maximum yields in both grain and straw were obtained at $40 \mathrm{Mg} \mathrm{ha}^{-1}$ of sewage sludge application. Al-Mustafa et al. (1995), Singh and Singh (1999), Al Zoubi et al. (2008) and Ailincăi et al. (2010) also mentioned highest increase in the grain and straw yield of wheat treated with sewage sludge.

Table 5. Influence of treated sewage sludge (TSS) applications on grain yield of second crop wheat grown in sandy clay soil Tukey: $\mathrm{P} \leq 0,01$

\begin{tabular}{|c|c|c|c|c|c|}
\hline Applications & Control & Fertilizer & $\begin{array}{l}12.5 \\
\text { Mg.ha }^{-1} \text { TSS }\end{array}$ & $\begin{array}{l}25.0 \\
\text { Mg.ha-1TSS }\end{array}$ & $\begin{array}{l}37.5 \\
\text { Mg.ha }^{-1} \text { TSS }\end{array}$ \\
\hline Grain yield of second crop wheat (Mg.ha' $\left.{ }^{-1}\right)$ & $1.486 \mathrm{~b}^{1}$ & $2.270 \mathrm{ab}$ & $1.883 \mathrm{ab}$ & $2.259 \mathrm{ab}$ & $2.609 \mathrm{a}$ \\
\hline
\end{tabular}

\section{Influence of TSS applications on some properties of sandy clay soil}

Influence of TSS applications on total $\mathrm{N}$ content of sandy clay soil is given in Table 6 .

The increasing TSS rates significantly increased total $\mathrm{N}$ concentration of the average of 5 sampling periods of soil compared with the control. Total $\mathrm{N}$ concentration in the soil decreased particularly in the last periods because of the plant uptake of $\mathrm{N}$ in soil. Brofas et al. (2000) stated that $\mathrm{N}$ concentration increased with sludge applications. Bozkurt and Cimrin (2003) determined that sewage sludge applications increased the total $\mathrm{N}$ concentration about fivefold at the highest sludge rate. White et al. (1997) found that $\mathrm{N}$ mineralization potentials were significantly higher at high sludge rates. Magdoff and Amadon (1980) estimated that $55 \%$ of organic $\mathrm{N}$ in sludge incorporated in soil was mineralized during the first year. Under optimum laboratory conditions at a temperature of $35^{\circ} \mathrm{C}, 55$ to $95 \%$ of the organic $\mathrm{N}$ was mineralized in a 24 -week period. The rate of mineralization is a function of the amount of the sludge added to soil. A good $\mathrm{N}$ balance is a critical factor in any land application program. Over application of $\mathrm{N}$ can result in groundwater contamination. Under application can lead to less than optimum crop yields and consequently to farmer dissatisfaction. It is important that sufficient sludge is applied to obtain optimum crop response without excessive $\mathrm{NO}_{3}$-leaching. Further investigation is needed to develop more precise methods for balancing $\mathrm{N}$ from different sludge types and for varying soil conditions.

Table 6. Influence of treated sewage sludge (TSS) applications on total $\mathrm{N}$ content of sandy clay soil Total N (\%) Tukey:P $\leq 0,01$

\begin{tabular}{|c|c|c|c|c|c|c|c|c|c|c|c|}
\hline \multirow{2}{*}{ Applications } & \multirow{2}{*}{$\begin{array}{c}\text { Average } \\
\text { of } 5 \\
\text { periods }\end{array}$} & \multicolumn{9}{|c|}{ Soil sampling periods } & \\
\hline & & \multicolumn{2}{|l|}{1} & \multicolumn{2}{|l|}{2} & \multicolumn{2}{|c|}{3} & \multicolumn{2}{|c|}{4} & \multicolumn{2}{|l|}{5} \\
\hline Control & $0.083 \mathrm{~b}^{1}$ & $0.099 \mathrm{c}$ & $\mathrm{A}^{2}$ & $0.101 \mathrm{~b}$ & $\mathrm{~A}$ & $0.086 \mathrm{a}$ & $\mathrm{A}$ & $0.085 \mathrm{a}$ & A & $0.045 \mathrm{a} \quad \mathrm{B}$ & $* *$ \\
\hline Fertilizer & $0.088 \mathrm{~b}$ & $0.110 \mathrm{bc}$ & A & $0.108 \mathrm{~b}$ & A & $0.081 \mathrm{a}$ & A & $0.098 \mathrm{a}$ & A & $0.041 \mathrm{a} \quad \mathrm{B}$ & $* *$ \\
\hline 12.5 Mg.ha ${ }^{-1} \mathrm{TSS}$ & $0.090 \mathrm{ab}$ & $0.118 \mathrm{bc}$ & $\mathrm{A}$ & $0.109 \mathrm{~b}$ & A & $0.095 \mathrm{a}$ & A & $0.084 \mathrm{a}$ & A & $0.043 \mathrm{a} \quad \mathrm{B}$ & $* *$ \\
\hline 25.0 Mg.ha-1 TSS & $0.098 \mathrm{ab}$ & $0.134 \mathrm{ab}$ & A & $0.131 \mathrm{ab}$ & A & $0.082 \mathrm{a}$ & $\mathrm{B}$ & $0.101 \mathrm{a}$ & $\mathrm{AB}$ & $0.044 \mathrm{a} \quad \mathrm{C}$ & $* *$ \\
\hline 37.5 Mg.ha ${ }^{-1} \mathrm{TSS}$ & $0.109 \mathrm{a}$ & $0.157 \mathrm{a}$ & A & $0.153 \mathrm{a}$ & A & $0.085 \mathrm{a}$ & $\mathrm{B}$ & $0.107 \mathrm{a}$ & $\mathrm{B}$ & $0.043 \mathrm{a} \quad \mathrm{C}$ & $* *$ \\
\hline
\end{tabular}

Significant differences between treatments at $* * \mathrm{P} \leq 0,01$ level indicated by different letters. ${ }^{1}$ Small letter in column for applications, ${ }^{2}$ capital letter in row for periods.

Influence of TSS applications on plant available $\mathrm{P}$ content of sandy clay soil is given in Table 7 .

Applications of increasing TSS rates significantly increased the plant available $\mathrm{P}$ concentrations of soil in 5 different soil sampling periods according to the control. In the course of time, depending on decomposition of OM and using of plant available $\mathrm{P}$ in soil by produced plants, the effect of TSS rates on plant available $P$ concentrations in soil decreased especially in the last periods. White et al.
(1997) and Brofas et al. (2000) also reported a remarkable increase in plant available $\mathrm{P}$ in soil after the application of sewage sludge. Another study showed that $\mathrm{P}$ concentrations increased more than six-fold from control to the highest application rate plots (Sullivan et al. 2006). Rathod et al. (2013) reported that the beneficial effect of organics on $\mathrm{P}$ availability was possibly due to the solubilization of native phosphate by organic acids released during microbial decomposition of organic materials. 
Table 7. Influence of treated sewage sludge (TSS) applications on plant available ( $\mathrm{NaHCO}_{3}$-extractable) $\mathrm{P}$ content of sandy clay soil Available $\mathrm{P}\left(\mathrm{mg}^{\mathrm{kg}} \mathrm{kg}^{-1}\right)$, Tukey:P$\leq 0,01$

\begin{tabular}{|c|c|c|c|c|c|c|c|c|c|c|c|c|}
\hline \multirow{2}{*}{ Applications } & \multirow{2}{*}{$\begin{array}{c}\text { Average } \\
\text { of } 5 \\
\text { periods }\end{array}$} & \multicolumn{11}{|c|}{ Soil sampling periods } \\
\hline & & \multicolumn{2}{|l|}{1} & \multicolumn{2}{|l|}{2} & \multicolumn{2}{|l|}{3} & \multicolumn{2}{|l|}{4} & \multicolumn{3}{|l|}{5} \\
\hline Control & $41.19 \mathrm{~d}^{1}$ & $63.68 \mathrm{c}$ & $\mathrm{A}^{2}$ & $27.25 \mathrm{c}$ & $\mathrm{B}$ & $46.14 \mathrm{c}$ & $\mathrm{AB}$ & $37.21 \mathrm{c}$ & B & $31.65 \mathrm{c}$ & B & $* *$ \\
\hline Fertilizer & $61.42 \mathrm{bc}$ & $73.85 \mathrm{c}$ & $\mathrm{A}$ & $43.20 \mathrm{c}$ & $\mathrm{B}$ & $78.02 \mathrm{~b}$ & A & $63.05 \mathrm{ab}$ & $\mathrm{AB}$ & $49.00 \mathrm{bc}$ & $\mathrm{B}$ & $* *$ \\
\hline 12.5 Mg.ha-1TSS & $53.70 \mathrm{~cd}$ & $67.94 \mathrm{c}$ & $\mathrm{A}$ & $39.90 \mathrm{c}$ & $\mathrm{B}$ & $63.10 \mathrm{bc}$ & A & $51.05 \mathrm{bc}$ & $\mathrm{AB}$ & $46.50 \mathrm{bc}$ & $\mathrm{AB}$ & $* *$ \\
\hline 25.0 Mg.ha ${ }^{-1} \mathrm{TSS}$ & $73.18 \mathrm{~b}$ & $96.89 \mathrm{~b}$ & $\mathrm{~A}$ & $79.30 \mathrm{~b}$ & A & $82.72 \mathrm{~b}$ & A & $53.07 \mathrm{bc}$ & $\mathrm{B}$ & $53.94 \mathrm{~b}$ & B & $* *$ \\
\hline 37.5 Mg.ha-1 TSS & $103.29 \mathrm{a}$ & $121.02 \mathrm{a}$ & $\mathrm{A}$ & $111.90 \mathrm{a}$ & $\mathrm{A}$ & $121.58 \mathrm{a}$ & A & $81.49 \mathrm{a}$ & $\mathrm{B}$ & $80.45 \mathrm{a}$ & $\mathrm{B}$ & $* *$ \\
\hline
\end{tabular}

Significant differences between treatments at $* * \mathrm{P} \leq 0,01$ or $* \mathrm{P} \leq 0,05$ level indicated by different letters. ${ }^{1}$ Small letter in column for applications, ${ }^{2}$ capital letter in row for periods.

Influence of TSS applications on plant available $\mathrm{K}$ content of sandy clay soil is given in Table 8 .

Increasing TSS rates and mineral fertilizer applications significantly increased available $\mathrm{K}$ concentration of the average of 5 sampling periods of soil compared with the control. Delibacak et al. (2009a) found that, plant available
$\mathrm{K}$ increased with TSS rates from $340 \mathrm{mg} \mathrm{kg}^{-1}$ in the control plots to $419 \mathrm{mg} \mathrm{kg}^{-1}$ with the $90 \mathrm{Mg} \mathrm{ha}^{-1}$ application rate. On the other hand, Marti'nez et al. (2003) noted that, plant available K concentrations in soil were low and did not increase significantly with biosolid treatments compared with the control.

Table 8. Influence of treated sewage sludge (TSS) applications on plant available ( $1 \mathrm{~N} \mathrm{NH}_{4} \mathrm{OAc}$ - extractable) $\mathrm{K}$ content of sandy clay soil, Available K (mg.kg $\left.{ }^{-1}\right)$, Tukey:P $\leq 0,01 ; \mathrm{P} \leq 0,05$

\begin{tabular}{|c|c|c|c|c|c|c|c|c|c|c|c|}
\hline \multirow{2}{*}{ Applications } & \multirow{2}{*}{$\begin{array}{c}\text { Average } \\
\text { of } \\
5 \text { periods }\end{array}$} & \multicolumn{10}{|c|}{ Soil sampling periods } \\
\hline & & 1 & & 2 & & 3 & 4 & & 5 & & \\
\hline Control & $168.81 \mathrm{c}^{1}$ & $188.83 \mathrm{~b}$ & $\mathrm{~A}^{2}$ & $175.23 \mathrm{ab}$ & $\mathrm{AB}$ & $168.50 \mathrm{a} \mathrm{AB}$ & $161.73 \mathrm{~b}$ & $\mathrm{AB}$ & $149.79 \mathrm{~b}$ & $\mathrm{~B}$ & $* *$ \\
\hline Fertilizer & $211.35 \mathrm{a}$ & $213.29 \mathrm{ab}$ & $\mathrm{B}$ & $207.10 \mathrm{a}$ & B & $190.34 \mathrm{a} \quad \mathrm{B}$ & $259.25 \mathrm{a}$ & A & $186.75 \mathrm{a}$ & B & $* *$ \\
\hline 12.5 Mg.ha ${ }^{-1} \mathrm{TSS}$ & $171.95 \mathrm{bc}$ & $191.16 \mathrm{~b}$ & A & $165.93 \mathrm{~b}$ & $\mathrm{AB}$ & $181.77 \mathrm{a} \quad \mathrm{AB}$ & $164.58 \mathrm{~b}$ & $\mathrm{AB}$ & $156.33 \mathrm{ab}$ & B & $*$ \\
\hline $25.0 \mathrm{Mg} \cdot \mathrm{ha}^{-1} \mathrm{TSS}$ & $179.34 \mathrm{bc}$ & $205.15 \mathrm{ab}$ & A & $180.49 \mathrm{ab}$ & $\mathrm{AB}$ & 176.87 a $\mathrm{AB}$ & $168.28 \mathrm{~b}$ & B & $165.92 \mathrm{ab}$ & $\mathrm{B}$ & $* *$ \\
\hline 37.5 Mg.ha ${ }^{-1} \mathrm{TSS}$ & $190.71 \mathrm{~b}$ & $226.13 \mathrm{a}$ & $\mathrm{A}$ & $184.85 \mathrm{ab}$ & $\mathrm{B}$ & $180.34 \mathrm{a} \quad \mathrm{B}$ & $179.65 \mathrm{~b}$ & $\mathrm{~B}$ & $182.60 \mathrm{ab}$ & $\mathrm{B}$ & $* *$ \\
\hline
\end{tabular}

Significant differences between treatments at $* * \mathrm{P} \leq 0,01$ level indicated by different letters. ${ }^{1}$ Small letter in column for applications, ${ }^{2}$ capital letter in row for periods.

Influence of TSS applications on $\mathrm{pH}$ of sandy clay soil is given in Table 9.

The increasing TSS rates significantly increased $\mathrm{pH}$ values of the average of 5 sampling periods of soil according to the control and mineral fertizer applications. It can be said that the reason of increasing $\mathrm{pH}$ value of soil is high $\mathrm{pH}$ values of sewage sludge treated with lime to eliminate the pathogens. It is recommended that soil $\mathrm{pH}$ should be maintained above 6.5 for sludge amended soils (Henning et al. 2001). Smith (1994) noted that optimal pH value for growth of the majority of plants was between 6.5 and 7.0. The soil $\mathrm{pH}$ is also one of the major factors controlling the availability of heavy metals.

Table 9. Influence of treated sewage sludge (TSS) applications on $\mathrm{pH}$ of sandy clay soil, $\mathrm{pH}$ Tukey: $\mathrm{P} \leq 0,01 ; \mathrm{P} \leq 0,05$

\begin{tabular}{|c|c|c|c|c|c|c|c|c|c|c|c|c|}
\hline \multirow{2}{*}{ Applications } & \multirow{2}{*}{$\begin{array}{c}\text { Average } \\
\text { of } \\
5 \text { periods } \\
\end{array}$} & \multicolumn{10}{|c|}{ Soil sampling periods } & \\
\hline & & \multicolumn{2}{|c|}{1} & \multicolumn{2}{|l|}{2} & \multicolumn{2}{|c|}{3} & \multicolumn{2}{|l|}{4} & \multicolumn{3}{|c|}{5} \\
\hline Control & $7.33 \mathrm{ab}^{1}$ & $7.42 \mathrm{ab}$ & $\mathrm{AB}^{2}$ & $7.47 \mathrm{ab}$ & A & $7.22 \mathrm{ab}$ & B & $7.22 \mathrm{ab}$ & $\mathrm{AB}$ & $7.49 \mathrm{ab}$ & A & $*$ \\
\hline Fertilizer & $7.09 \mathrm{~b}$ & $7.13 \mathrm{~b}$ & $\mathrm{ABC}$ & $7.37 \mathrm{~b}$ & A & $6.79 \mathrm{~b}$ & $\mathrm{BC}$ & $6.79 \mathrm{~b}$ & $\mathrm{C}$ & $7.24 \mathrm{~b}$ & $\mathrm{AB}$ & $* *$ \\
\hline 12.5 Mg.ha-1 TSS & $7.54 \mathrm{a}$ & $7.47 \mathrm{ab}$ & $\mathrm{AB}$ & $7.77 \mathrm{a}$ & A & $7.53 \mathrm{a}$ & B & $7.53 \mathrm{a}$ & $\mathrm{AB}$ & $7.66 \mathrm{a}$ & $\mathrm{AB}$ & $* *$ \\
\hline 25.0 Mg.ha-1 TSS & $7.56 \mathrm{a}$ & $7.60 \mathrm{a}$ & $\mathrm{AB}$ & $7.69 \mathrm{ab}$ & A & $7.56 \mathrm{a}$ & B & $7.56 \mathrm{a}$ & $\mathrm{AB}$ & $7.67 \mathrm{a}$ & A & $*$ \\
\hline 37.5 Mg.ha-1 TSS & $7.55 \mathrm{a}$ & $7.51 \mathrm{ab}$ & $\mathrm{AB}$ & $7.71 \mathrm{ab}$ & A & $7.57 \mathrm{a}$ & B & $7.57 \mathrm{a}$ & $\mathrm{AB}$ & $7.64 \mathrm{a}$ & $\mathrm{AB}$ & $*$ \\
\hline
\end{tabular}

Significant differences between treatments at ** $\mathrm{P} \leq 0,01$ level indicated by different letters. ${ }^{1}$ Small letter in column for applications, ${ }^{2}$ capital letter in row for periods. 
Influence of TSS applications on total salt content of sandy clay soil is given in Table 10 .

It was found that, total salt content of soil was significantly increased by increasing TSS levels in average of 5 sampling periods of soil compared with the control.
The highest total salt was $0.202 \%$ with $37.5 \mathrm{Mg}^{-h^{-1}}{ }^{-1}$ TSS level. On the other hand, control had the lowest total salt as $0.136 \%$ (Table 10). In the last three periods, all salt contents of soil samples were statistically in the same grup. It can be said that irrigation and precipitation caused this situation.

Table 10. Influence of treated sewage sludge (TSS) applications on total salt content of sandy clay soil, Total salt (\%) Tukey:P $\leq 0,01$

\begin{tabular}{|c|c|c|c|c|c|c|c|c|c|c|c|}
\hline \multirow{2}{*}{ Applications } & \multirow{2}{*}{$\begin{array}{c}\text { Average } \\
\text { of } \\
5 \text { periods } \\
\end{array}$} & \multicolumn{10}{|c|}{ Soil sampling periods } \\
\hline & & \multicolumn{2}{|c|}{1} & \multicolumn{2}{|l|}{2} & \multicolumn{2}{|l|}{3} & 4 & \multicolumn{3}{|c|}{5} \\
\hline Control & $0.136 c^{1}$ & $0.165 \mathrm{c}$ & $\mathrm{AB}^{2}$ & $0.103 \mathrm{c}$ & $\mathrm{BC}$ & $0.070 \mathrm{a}$ & $\mathrm{C}$ & $0.186 \mathrm{a} \quad \mathrm{A}$ & $0.156 \mathrm{a}$ & $\mathrm{AB}$ & $* *$ \\
\hline Fertilizer & $0.160 \mathrm{bc}$ & $0.190 \mathrm{bc}$ & $\mathrm{AB}$ & $0.131 \mathrm{bc}$ & $\mathrm{BC}$ & $0.080 \mathrm{a}$ & $\mathrm{C}$ & $0.241 \mathrm{a} \quad \mathrm{A}$ & $0.157 \mathrm{a}$ & B & $* *$ \\
\hline 12.5 Mg.ha' ${ }^{-1} \mathrm{TSS}$ & $0.159 \mathrm{bc}$ & $0.228 \mathrm{bc}$ & A & $0.131 \mathrm{bc}$ & $\mathrm{BC}$ & $0.076 \mathrm{a}$ & $\mathrm{C}$ & $0.196 \mathrm{a} \quad \mathrm{AB}$ & $0.165 \mathrm{a}$ & $\mathrm{AB}$ & $* *$ \\
\hline 25.0 Mg.ha ${ }^{-1} \mathrm{TSS}$ & $0.178 \mathrm{ab}$ & $0.248 \mathrm{ab}$ & $\mathrm{A}$ & $0.174 \mathrm{ab}$ & B & $0.089 \mathrm{a}$ & $\mathrm{C}$ & $0.205 \mathrm{a} \quad \mathrm{AB}$ & $0.174 \mathrm{a}$ & $\mathrm{B}$ & $* *$ \\
\hline 37.5 Mg.ha' ${ }^{-1} \mathrm{TSS}$ & $0.202 \mathrm{a}$ & $0.288 \mathrm{a}$ & $\mathrm{A}$ & $0.230 \mathrm{a}$ & $\mathrm{AB}$ & $0.078 \mathrm{a}$ & $\mathrm{C}$ & $0.225 \mathrm{a} \quad \mathrm{AB}$ & $0.191 \mathrm{a}$ & $\mathrm{B}$ & $* *$ \\
\hline
\end{tabular}

Significant differences between treatments at $* * \mathrm{P} \leq 0,01$ level indicated by different letters. ${ }^{1}$ Small letter in column for applications, ${ }^{2}$ capital letter in row for periods.

Influence of TSS applications on $\mathrm{CaCO}_{3}$ content of sandy clay soil is given in Table 11 .

The increasing TSS rates were significantly increased $\mathrm{CaCO}_{3}$ content of the average of 5 sampling periods of soil compared with the control. It can be said that high $\mathrm{CaCO}_{3}$ content of TSS $(10.24 \%)$ caused this situation.

Influence of TSS applications on cation exchange capacity (CEC) of sandy clay soil is given in Table 12 .
It was found that, there is no statistical relationship between TSS levels and CEC of soil in all periods. Ahmed et al. (2010) determined that use of sewage sludge in soil showed higher nitrogen and phosphorus contents than the control soil, but a similar content of cation exchange capacity (CEC). On the other hand, Alcantara et al. (2009) observed that the concentrations of phosphorus, nitrogen, sulfate, and CEC, organic carbon were positively correlated with sewage sludge dose applied to the soil.

Table 11. Influence of treated sewage sludge (TSS) applications on $\mathrm{CaCO}_{3}$ content of sandy clay soil, $\mathrm{CaCO}_{3}(\%)$ Tukey:P $\leq 0,01 ; \mathrm{P} \leq 0,05$

\begin{tabular}{|c|c|c|c|c|c|c|c|c|c|c|c|c|}
\hline \multirow{2}{*}{ Applications } & \multirow{2}{*}{$\begin{array}{c}\text { Average of } 5 \\
\text { periods }\end{array}$} & \multicolumn{11}{|c|}{ Soil sampling periods } \\
\hline & & \multicolumn{2}{|l|}{1} & \multicolumn{2}{|c|}{2} & \multicolumn{2}{|l|}{3} & \multicolumn{2}{|c|}{4} & \multicolumn{3}{|l|}{5} \\
\hline Control & $0.617 \mathrm{c}^{1}$ & $0.445 \mathrm{~b}$ & $\mathrm{~B}^{2}$ & $0.592 \mathrm{a}$ & $\mathrm{AB}$ & $0.779 \mathrm{a}$ & $\mathrm{A}$ & $0.684 \mathrm{a}$ & $\mathrm{AB}$ & $0.584 \mathrm{~b}$ & $\mathrm{AB}$ & $* *$ \\
\hline Fertilizer & $0.630 \mathrm{bc}$ & $0.461 \mathrm{~b}$ & $\mathrm{~B}$ & $0.570 \mathrm{a}$ & $\mathrm{AB}$ & $0.794 \mathrm{a}$ & $\mathrm{A}$ & $0.677 \mathrm{a}$ & $\mathrm{AB}$ & $0.651 \mathrm{ab}$ & $\mathrm{AB}$ & $* *$ \\
\hline 12.5 Mg.ha-1 TSS & $0.673 \mathrm{abc}$ & $0.539 \mathrm{ab}$ & B & $0.547 \mathrm{a}$ & $\mathrm{B}$ & $0.824 \mathrm{a}$ & A & $0.818 \mathrm{a}$ & $\mathrm{A}$ & $0.636 \mathrm{ab}$ & $\mathrm{AB}$ & $* *$ \\
\hline 25.0 Mg.ha- $\mathrm{hSS}^{-1}$ & $0.769 \mathrm{ab}$ & $0.635 \mathrm{ab}$ & $\mathrm{B}$ & $0.713 \mathrm{a}$ & $\mathrm{AB}$ & $0.855 \mathrm{a}$ & A & $0.825 \mathrm{a}$ & $\mathrm{AB}$ & $0.815 \mathrm{ab}$ & $\mathrm{AB}$ & $*$ \\
\hline 37.5 Mg.ha- ${ }^{-1} \mathrm{TSS}$ & $0.795 \mathrm{a}$ & $0.684 \mathrm{a}$ & $\mathrm{A}$ & $0.714 \mathrm{a}$ & $\mathrm{A}$ & $0.855 \mathrm{a}$ & $\mathrm{A}$ & $0.848 \mathrm{a}$ & $\mathrm{A}$ & $0.847 \mathrm{a}$ & $\mathrm{A}$ & \\
\hline
\end{tabular}

$\overline{\text { Significant differences between treatments at } * * \mathrm{P} \leq 0,01 \text { or } * \mathrm{P} \leq 0,05 \text { level indicated by different letters. }{ }^{1} \text { Small letter in column for applications, }{ }^{2} \text { capital }}$ letter in row for periods.

Table 12. Influence of treated sewage sludge (TSS) applications on cation exchange capacity (CEC) of sandy clay soil, CEC (meq/100g), Tukey:P $\leq 0,05$

\begin{tabular}{|c|c|c|c|c|c|c|c|c|c|c|c|}
\hline \multirow{2}{*}{ Applications } & \multirow{2}{*}{$\begin{array}{c}\text { Average of } 5 \\
\text { periods }\end{array}$} & \multicolumn{10}{|c|}{ Soil sampling periods } \\
\hline & & 1 & 2 & & 3 & & 4 & & 5 & & \\
\hline Control & $25.95 \mathrm{a}^{1}$ & $27.35 \mathrm{a} \quad \mathrm{A}^{2}$ & $26.26 \mathrm{a}$ & $\mathrm{A}$ & $25.10 \mathrm{a}$ & $\mathrm{A}$ & $25.66 \mathrm{a}$ & A & $25.37 \mathrm{a}$ & A & \\
\hline Fertilizer & $25.83 \mathrm{a}$ & $27.26 \mathrm{a} \quad \mathrm{A}$ & $25.27 \mathrm{a}$ & $\mathrm{AB}$ & $25.23 \mathrm{a}$ & $\mathrm{AB}$ & $26.85 \mathrm{a}$ & $\mathrm{AB}$ & $24.52 \mathrm{a}$ & $\mathrm{B}$ & $*$ \\
\hline 12.5 Mg.ha-1 TSS & $26.73 \mathrm{a}$ & $28.08 \mathrm{a} \mathrm{A}$ & $26.99 \mathrm{a}$ & $\mathrm{A}$ & $25.85 \mathrm{a}$ & $\mathrm{A}$ & $27.10 \mathrm{a}$ & A & $25.62 \mathrm{a}$ & A & \\
\hline 25.0 Mg.ha ${ }^{-1} \mathrm{TSS}$ & $26.71 \mathrm{a}$ & 27.08 a A & $26.90 \mathrm{a}$ & A & $25.96 \mathrm{a}$ & A & $27.50 \mathrm{a}$ & A & $26.12 \mathrm{a}$ & A & \\
\hline 37.5 Mg.ha-1 TSS & $27.01 \mathrm{a}$ & $26.63 \mathrm{a} \mathrm{A}$ & $26.99 \mathrm{a}$ & A & $26.59 \mathrm{a}$ & A & $27.90 \mathrm{a}$ & A & $26.92 \mathrm{a}$ & A & \\
\hline
\end{tabular}

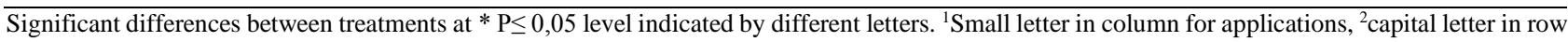
for periods. 
Influence of TSS applications on organic matter content of sandy clay soil is given in Table 13 .

Treatments of increasing TSS levels significantly increased OM content of soil samples in the average of 5 periods. Analogously to our study, Delibacak et al. (2009b) found out an increase in the concentrations of OM in soil caused by increasing doses of sewage sludge introduced to soil.

Table 13. Influence of treated sewage sludge (TSS) applications on organic matter (OM) content of sandy clay soil, OM (\%) Tukey: $\mathrm{P} \leq 0,01 ; \mathrm{P} \leq 0,05$

\begin{tabular}{|c|c|c|c|c|c|c|c|c|c|c|c|c|}
\hline \multirow{2}{*}{ Applications } & \multirow{2}{*}{$\begin{array}{c}\text { Average of } 5 \\
\text { periods }\end{array}$} & \multicolumn{11}{|c|}{ Soil sampling periods } \\
\hline & & \multicolumn{2}{|c|}{1} & \multicolumn{2}{|l|}{2} & \multicolumn{2}{|c|}{3} & \multicolumn{2}{|c|}{4} & \multicolumn{3}{|c|}{5} \\
\hline Control & $1.40 \mathrm{~b}^{1}$ & $1.21 \mathrm{~b}$ & $\mathrm{~B}^{2}$ & $1.19 \mathrm{~b}$ & $\mathrm{~B}$ & $1.72 \mathrm{a}$ & $\mathrm{A}$ & $1.49 \mathrm{a}$ & $\mathrm{AB}$ & $1.36 \mathrm{a}$ & $\mathrm{AB}$ & $* *$ \\
\hline Fertilizer & $1.43 \mathrm{ab}$ & $1.29 \mathrm{ab}$ & $\mathrm{B}$ & $1.27 \mathrm{ab}$ & B & $1.79 \mathrm{a}$ & $\mathrm{A}$ & $1.48 \mathrm{a}$ & $\mathrm{AB}$ & $1.33 \mathrm{a}$ & B & $* *$ \\
\hline 12.5 Mg.ha-1 TSS & $1.48 \mathrm{ab}$ & $1.32 \mathrm{ab}$ & B & $1.36 \mathrm{ab}$ & $\mathrm{B}$ & $1.78 \mathrm{a}$ & $\mathrm{A}$ & $1.53 \mathrm{a}$ & $\mathrm{AB}$ & $1.42 \mathrm{a}$ & $\mathrm{AB}$ & $* *$ \\
\hline 25.0 Mg.ha-1 TSS & $1.54 \mathrm{ab}$ & $1.47 \mathrm{ab}$ & A & $1.47 \mathrm{ab}$ & A & $1.77 \mathrm{a}$ & $\mathrm{A}$ & $1.52 \mathrm{a}$ & $\mathrm{A}$ & $1.45 \mathrm{a}$ & A & \\
\hline 37.5 Mg.ha-1 TSS & $1.61 \mathrm{a}$ & $1.65 \mathrm{a}$ & A & $1.64 \mathrm{a}$ & A & $1.68 \mathrm{a}$ & A & $1.57 \mathrm{a}$ & A & $1.53 \mathrm{a}$ & A & \\
\hline
\end{tabular}

Significant differences between treatments at $* * \mathrm{P} \leq 0,01$ level indicated by different letters. ${ }^{1}$ Small letter in column for applications, ${ }^{2}$ capital letter in row for periods.

\section{CONCLUSION}

Increasing TSS applications to sandy clay soil resulted in significantly increased total biomass and grain yield of corn and grain yield of second crop wheat according to the control. Also, increasing treated sewage sludge aplications were significiantly increased total $\mathrm{N}$, plant available $\mathrm{P}$ and $\mathrm{K}, \mathrm{pH}$, total salt, $\mathrm{CaCO}_{3}$ and organic matter content of sandy clay soil as average of 5 sampling periods . However, CEC values of soil did not change significantly as average of 5 sampling periods when compared with the control. In the course of time, effect of TSS levels on soil properties decreased particularly in the last periods due to decomposition of TSS in soil. For this reason, it is

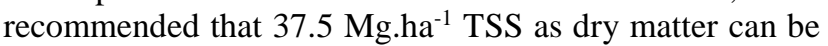
added once in 2 years for having more yield and improving soil properties of sandy clay soil under Mediterranean climate, which are characterized by low OM content and high $\mathrm{pH}$. Sewage sludge application to agricultural land has been a widely accepted practice during recent years. Its use in agricultural land is promoted because it is considered that it will solve not only the problem of disposal but also will increase productivity in agriculture. Further investigations are necessary to quantify the fertiliser replacement value of plant nutrients. In particular, accurately characterising the $P$ fertiliser replacement value of sewage sludge will become an increasingly important issue for effective $\mathrm{P}$ recycling in agricultural production and food security in future as geological $\mathrm{P}$ reserves are depleted and $\mathrm{P}$ fertiliser costs increase. At levels above the agronomic recommended rate, however, the potential for negative externalities may be quite substantial. Monitoring the soil periodically for nutrient levels would be prudent to avoid any excess levels on $\mathrm{N}$ or other plant nutrient. More continuous long-term experiments are needed to improve the understanding of the effects of sewage sludge on soil fertility and crop yield to contribute to the development of sustainable agricultural practices. However, negative effects of sewage sludge such as elevated heavy metal levels resulting from the usage of sewage sludge must also be taken into consideration (Smith 1996). Sewage sludge containing pathogenic organisms should be handled and applied in a proper manner to reduce the risks to human and animal health. Finally, the application of TSS to soil must obey the limited regulations. After the analysis of sewage sludge and soil, a governmental permission is needed to apply them to agricultural lands in Turkey.

\section{ACKNOWLEDGEMENTS}

This work was supported by The Scientific and Technical Research Council of Turkey (TUBITAK) under Grant (number 108G167).

\section{LITERATURE CITED}

Aggelides, S.M. and P.A. Londra. 2000. Effect of compost produced from town wastes and sewage sludge on the physical properties of a loamy and a clay soil. Bioresource Technology, 71, 253-259.

Ahmed, H.K., H.A. Fawy and E.S. Abdel-Hady. 2010. Study of sewage sludge use in agriculture and its effect on plant and soil. Agric. Biol. J. N. Am., 1(5): 1044-1049.

Ailincăi, C., G. Jităreanu, D. Ailincăi and A. Balan. 2010. Influence of some organic residues on wheat and maize yield and eroded soil fertility. Cercetări agronomice in Moldova Vol. XLIII, No. 1 (141).

Al Zoubi, M.M., A. Arslan, G. Abdelgawad, N. Pejon, M. Tabbaa and O. Jouzdan. 2008. The effect of sewage sludge on productivity of a crop rotation of wheat, maize and vetch) and heavy metals accumulation in soil and plant in Aleppo governorate. American-Eurasian Journal of Agriculture and Environmental Sciences 3(4), 618-625.

Alcantara, S., D.V. Pérez, R.A. Almeida, G.M. Silva, J.C. Polidoro and W. Bettiol. 2009. Chemical changes and heavy metal partitioning in an oxisol cultivated with maize (Zea mays L.) after 5 years disposal of a domestic and an Industrial sewage sludge. Water, Air, and Soil Pollution 203, 3-16.

Al-Mustafa, W.A., A.A. El-Shall, A.E. Abdallah and A.S. Modaihsh. 1995. Response of wheat to sewage sludge applied under two different moisture regimes. Experimental Agriculture 31, 355-9.

Antoli'n, M.C., I. Pascual, C. Garcia, A. Polo and M . SanchezDiaz. 2005. Growth, yield and solute content of barley in soils 
treated with sewage sludge under semiarid Mediterranean conditions. Field Crops Research 94, 224-237.

Barker, A.V., M.L. Stratton and J.E. Rechcigl. 2000. Soil and byproduct characteristics that impact the beneficial use of byproducts. Pages 169-213 in W. A. Dick et al. eds. Land application of Agricultural, Industrial, and Municipal byproducts. SSSA, Madison, WI.

Benitez, E., M. Romero, M. Gomez, F. Gallardolaro and F. Nogales. 2001. Biosolid and biosolid ash as sources of heavy metals in plant-soil system. Water, Air and Soil Pollution, 132, 75-87.

Bouyoucos, G.J.1962. Hydrometer method improved for making particle size analysis of soil. Agronomy Journal, 54(5), 464465.

Bozkurt, M.A. and K.M. Cimrin. 2003. The Effects Of Sewage Sludge Applications on Nutrient And Heavy Metal Concentration in a Calcareous Soil. FEB/ Vol 12/ No 11/ 2003- pages 1354-1360.

Bremner, J.M. 1965. 'Total Nitrogen', in C. A. Black (Ed.). Methods of Soil Analysis. Part 2, American Society of Agronomy Inc., Madison, Wisconsin, USA. 1149-1178.

Brofas, G., P. Michopoulos and D. Alifragis. 2000. Sewage sludge as an amendment for calcareous bauxite mine spoils reclamation. J Environ Qual 29:811-816.

Chapman, H.D., 1965. Cation-exchange capacity. In: C.A. Black (ed.). Methods of soil analysis - Chemical and microbiological properties. Agronomy 9:891-901.

Christie, P., D.L. Easson, J.R. Picton and S.C.P. Love. 2001. Agronomic value of alkaline-stabilized sewage biosolids for spring barley. Agron. J. 93, 144-151.

Cogger, C.G., A.I. Bary, D.M. Sullivan and E.A. Myhre. 2004. Biosolids processing effects on first and second year available nitrogen. Soil Sci Soc Am J. 68:162-167.

Corre`a, R.S. 2004. Efficiency of five biosolids to supply nitrogen and phosphorus to ryegrass. Pesq. Agropec. Bras., 39:11331139, 2004.

Daur, I., A.O. Abusuwar and F. Alghabari. 2015. Exploitation of em.1-treated blend of organic resources and humic acid for organic berseem (trifolium alexandrinum 1.) Production. Turk J. of Field Crops, 20(2), 125-130.

Debosz, K., S.O. Petersen, L.K. Kure and P. Ambus. 2002 Evaluating effects of sewage sludge and household compost on soil physical, chemical and microbiological properties. Applied Soil Ecology, 19(3), 237-248.

Defra. 2010. Policy narrative on global food security and sustainable agriculture, London: DEFRA

Delibacak, S., B. Okur and A.R. Ongun. 2009a. Influence of treated sewage sludge applications on temporal variations of plant nutrients and heavy metals in a Typic Xerofluvent soil. Nutr. Cycl. Agroecosyst., 83: 249-257.

Delibacak, S., B. Okur and A.R. Ongun. 2009b. Effects of treated sewage sludge levels on temporal variations of some soil properties of a Typic Xerofluvent soil in Menemen Plain, Western Anatolia, Turkey. Environmental Monitoring and Assessment, 148: 85-95.

Henning, B.J., H.G. Snyman and T.A.S. Aveling. 2001. Plant-soil interactions of sludge-borne heavy metals and the effect on maize (Zea mays L.) seedling growth. Water SA 27(1):71-78.

Hernandez, T., J.I. Moreno and F. Costa. 1991. Influence of sewage sludge application on crop yields and heavy metal availability. Soil Science and Plant Nutrition 37, 201-210.

IARTC. 2012. Weather Station Climate Datas of International Agricultural Research and Traning Center. Menemen, İzmir.

Jamil, M., M. Qacim and M. Umar. 2006. Utilization of sewage sludge as organic fertilizer in sustainable agriculture. Journal of Applied Science 6, 531-535.
Jamil, M., M. Qasim, M. Umar and K. Rehman. 2004. Impact of organic wastes (sewage sludge) on the yield of wheat (Triticum aestivum L.) in a calcareous soil. International Journal of Agriculture and Biology 6(3), 465-467.

Kacar, B. 1994. Chemical analysis of plant and soil: III soil analysis. Ankara University, Faculty of Agriculture, Education Res. and Extension Found. Publications: 3 Ankara (in Turkish)

Magdoff, F.R. and J.F. Amadon. 1980. Nitrogen availability from sewage sludge. J Environ Qual 9:451-455

Martı'nez, F., G. Cuevas, R. Calvo and I. Walter. 2003. Biowaste effects on soil and native plants in a semiarid ecosystem. J Environ Qual 32:472-479.

Mercik, S., W. Stêpieñ and M. Gêbski. 2003. Uptake by plants and solubility of $\mathrm{Cu}, \mathrm{Zn}, \mathrm{Pb}$ and $\mathrm{Cd}$ in different extraction solutions depending on soil acidity. Zesz. Probl. Post. Nauk Rol., 493: 913-921.

Navas, A., F. Bermu'dez and J. Machı'n. 1998. Influence of sewage sludge application on physical and chemical properties of Gypsisols. Geoderma 87, 123-135.

Olsen, S.R., C.V. Cole, F.S. Watanabe and L.A. Dean. 1954. Estimation of available phosphorus in soil by extraction with sodium bicarbonate. U.S. Dep. Agric.Circ.939, USDA Washington, DC.

Page, A.L., R.H. Miller and D.R. Keeney (Eds.). 1982. In:Methods of soil analysis. Part 2. Chemical and microbiological properties, 2nd ed. Agron. Monogr. 9. ASASSA, Madison, USA.

Pascual, I., M.C. Antolín, C. García, A. Polo and M. SánchezDíaz. 2004. Plant availability of heavy metals in a soil amended with a high dose of sewage sludge under drought conditions. Biol. Fertil. Soils, 40: 291-299.

Rathod, D.D., P.H. Rathod, K.P. Patel and K.C. Patel. 2013. Integrated use of organic and inorganic inputs in wheat-fodder maize cropping sequence to improve crop yields and soil properties. Archives of Agronomy and Soil Science, Vol. 59, No. 11, 1439-1455.

Selivanovskaya, S.Y., V.Z. Latypova, S.N. Kiyamova and F.K. Alimova. 2001. Use of microbial parameters to access treatment methods of municipal sewage sludge applied to grey forest soils of Tatarstan. Agriculture, Ecosystem and Environment, 86, 145-153.

Sequi, P., F. Tittarelli and A. Bendetti. 2000. The role of sludge on the reintegration of soil fertility.-in: in: Langenkamp, $\mathrm{H}$. and L. Marmo (Eds.) 120-132.

Singh, C.P.J. and S.S. Singh. 1999. Effect of urea and sludge based compost application on the yield of wheat (Triticum aestivum L.). Madras Agricultural Journal 86, 511-3.

Smith, S.R. 1994. Effect of soil pH on availability to crops of metals in sewage sludge-created soils. I. Nickel, copper and zinc uptake and toxicity to ryegrass. Environ Pollut 85(3):321-327. doi:10.1016/0269-7491(94)90054-X

Smith, S.R. 1996. Agricultural recycling of sewage sludge and the environment. p. 155-206. In Nutrients. CAB Int., Wallingford, UK.

Soil Survey Staff. 2006. Keys to soil taxonomy. 10th ed. Washington DC, USA: US Government Printing Office.

SPSS 17.0. 2008. SPSS 17.0 for Windows. Chicago, IL, SPSS Inc.

Sullivan, T.S., M.E. Stromberger, M.W. Paschke and J.A. Ippolito. 2006. Long-term impacts of infrequent biosolids applications on chemical and microbial properties of a semiarid rangeland soil. Biol Fertil Soils 42: 258-266. DOI 10.1007/s00374-005-0023-z

Tamrabet, L., H. Bouzerzour, M. Kribaa and M. Makhlouf. 2009. The effect of sewage sludge application on durum wheat (Triticum durum). International Journal of Agriculture and Biology 11, 741-745. 
Tarraso'n, D., G. Ojeda, O. Ortiz and J.M. Alcaniz. 2008. Differences on nitrogen availability in a soil amended with fresh, composted and thermally-dried sewage sludge. Bioresource Technology 99, 252-259.

White, C.S., S.R Loftin, R. Aguilar. 1997. Application of biosolids to degraded semiarid rangeland: nine-year response. J. Environ. Qual. 26:1663-1671.
Wong, J.W. and D.C. Su. 1997. The growth of Agropyron elongatum in an artificial soil mix from coal fly ash and sewage sludge. Bioresource Technology, 59(1), 57-62 